\title{
The Global Governance OF INFECTIOUS DISEASES: THE WORLD HEALTH ORGaNizaTION AND THE INTERNATIONAL HEALTH REgULATIONS
}

\author{
ROSARIO M. ISASI AND ThU Minh NGUYIN"*
}

The 2003 SARS outbreak exemplified both the porous boundaries for infectious disease dine to globalization and the inadequacy of global governance of public heallh. The World Meallh Organization (IVHO), whose mission is to play a leading role in the protection and promotion of global public health. recently adopted a revision of its International Health Regulations (IHR). By revising and updating the IHR. it remains to be seen whether this new instrument can serve as a model for effective public healh governance, allowing the WHO ro fulfill its mandate. The atuhors provide background on the role and evolulion of the WIIO in global heallh governance. They then provide a comparative analysis benteen the 2005 IHR with the original 1969 IHR in terms of scope, procedure, response nerworks, capacities and respect for human rights.
L.'ipidemie de Sk.1S de 20033 a à la fois Illustré la perméabilite des fromhires aux maladies infectieuses en raison de la mondialisation et le manque d'ndaptation de la gomvernance mondiale de la sante' publique. L'Organisation mondiale de la santé (OAIS). dont la mission consiste à jouter un role de premier plan dans la protection et la promotion de la santé publique mondiale. vient d'adopter une révision du Règlemen saniaire international. En révisam le Règlement et en le metlan d̀ jour. il reste à voir si le nowvel instrument pewt servir de modele pour une gowvernance efficace de la santé publique. permenta ainsi à lOM/S de remplir son mandat. Les auteurs expliquem le coniexte du role el l'évolution de lOMIS dans la gouvernance mondiale de la santé. Its fournissem ensuite whe analyse comparative du RSI de 2005 avec celui de 1999 en ce qui concerne la poriée. la procédure. les réseaux de réponse. les copacilés et le respect des droits de la personne.

\section{TABLE OF CONTENIS}

I. INTRODUCTION ............................ 498

II. THE WORI.D HEALTH ORGinization's ROLL IN

GLOBAL HEALTH Govi:RnANCE . . . . . . . . . . . . . . . . . . 499

III. THE ORIGINAL (1969) VERSION OF THE INTIERNATIONAL.

Health Regulations and its Limitations $\ldots \ldots \ldots \ldots \ldots \ldots$. 501

IV. THE REvisEd INTERNATIONAL HEALTH

REgUl.ATIONS (2005) . . . . . . . . . . . . . . . . . . 502

A. REvised INTLRNATIONAI. HEAL.TH REgUI.ATIONS:

Corl: Obligations ........................ 505

B. REVISLD INTIERNATIONAI. HEAITH REGUU.ATIONS:

Corl: CapacitIES ........................ 506

C. REVISED INTERNATIONAL HEALTII REgULATIONS:

RESPECT FOR HUMAN RIGHTS . . . . . . . . . . . . . . . . . . . 507

- J.D. M.P.H. Postdoctoral leellow, Genetics and Society Project. Centre de recherche en droit public (CRDP), Universite de Montréal. Montreal, Quchec. The author wishes to thank Professor Bartha Maria Knoppers for her continuous guidance. This work was supported by the grant "Legal foundations for a National Disease Control and Surveillance Agency in Canada" from the Canadian Institutes of Health Research.

- B.Sc., L.L.B., Research Assistant, Centre de recherche en droit public (CRDP), Université de Montréal, Montreal, Quebec. 
V. The NEW INTERNATIONAl. HEAlth REgulations (2005):

A STEP FORWARD IN MODERN GlOBAL PUBLIC

HEALTH GOVERNANCE? . . . . . . . . . . . . . . . . . . . . 508

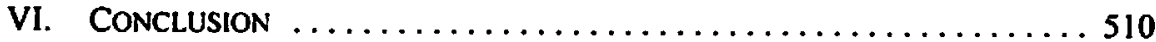

\section{INTRODUCTION}

Globalization has increased the potential for international spread of infectious diseases and has resulted in the need for adopting a multilateral approach to public health. Worldwide patterns and determinants of health and disease, and specifically infectious diseases, are changing dramatically due to globalization's erosion of traditional geographical, temporal and cognitive boundaries.' In the twentieth century, globalization became bi-directionally linked to health ${ }^{2}$ and has also become an unprecedented challenge to public health policy. Globalization has created a heightened need for appropriate global health governance structures ${ }^{3}$ and for stronger international cooperation in the protection and promotion of health.

In the foreseeable future, new pandemics, most likely caused by either influenza or the avian flu, will demonstrate to be substantial challenges to public health. Notwithstanding the influenza pandemics of 1918 and 1919 which caused over 50 million deaths worldwide, the experience of the SARS outbreak in 2003 demonstrated that the world community is still illprepared to effectively cope with such threats. ${ }^{4}$

The SARS outbreak constituted a benchmark in the World Health Organization (WHO)'s effort to claim power and authority "in the governance of global infectious disease threats"s as well as to obtain a critical role in shaping a modern public health system. As such, the significance of the SARS outbreak extends "well beyond the world of public health to encompass world politics generally."

Furthermore, the SARS outbreak illustrated the implications of public health on international security. The World Health Assembly (WHA) considered this severe infectious disease "a serious threat to global health security, the livelihood of populations, the functioning of health systems, and the stability and growth of economies." Due to the degree

$1 \quad$ Kelley Lee, "The impact of globalization on public health: implications for the UK Faculty of Public Health Medicine" (2000) 22 Journal of Public Health Medicine 254.

: David Woodward et al., "Globalization and health: a framework for analysis and action" (2001) 79 Bulletin of the World Health Organization 875.

Allyn L. Taylor, “Governing the Globalization of Public Health” (2004) 32 J.L. Med. \& Ethics 500. Dorothy Bonn, "Get ready now for the next flu pandemic" (2005) 5 The Lancet Infectious Diseases 139 ; "On a wing and a prayer," Editorial, Nature (26 May 2005) 385.

David P. Fidler, SARS, Governance and the Globalization of Disease (New York: Palgrave Macmillan, 2004) at 7.

lbid. at 8.

UN WHA, 56th Ass., 10th Plen. Mtg., Severe acute respiratony syndrome (SARS), WHA 56.29 (2003) at Preamble. 
of international cooperation during the SARS crisis, it was recognized that health was a "global public good"8 superseding national interests.

The emerging "global health governance" framework links the control of infectious diseases with the protection of global security. Thus, epidemic prone and emerging infectious diseases are considered to threaten "global health security." The protection of a population's health falls under the fundamental governmental role of preserving the security of its citizenry. However, for public health measures to be effective in a globalized world, they must cross national and international borders.

The revised International Health Regulations (IHR), recently adopted by the WHA, constitute another historical moment in the efforts to respond to global public health challenges. A global governance regime characterized by openness, transparency and international collaboration is required to ensure the protection of public health and to successfully deal with threats such as the HIV/AIDS pandemic, SARS and avian flu outbreaks, as well as a new influenza pandemic. Although the solutions must be locally implemented, they must be coordinated on an international scale. It remains to be seen if by strengthening the IHR, through clearly defined roles and responsibilities for both the WHO and member states, whether a modern and collective perspective to public health governance has been achieved.

This article presents a backgrounder on the evolving global governance of infectious diseases; focusing in particular on the WHO's global governance role in the protection and promotion of global health. Starting with an overview of the World Health Organization's structure, this paper will provide a comparative analysis between the original (1969) version of the International Health Regulations and the newly adopted revised version.

\section{THE World Health Organization's Role in Global. Heal.th Governance}

In the twenty-first century, the phenomenon of globalization has caused health issues to become a prominent item on the global political agenda. The HIV/AIDS pandemic and the SARS and avian influenza outbreaks, to cite three paradigmatic cases, demonstrated the complex implications of globalization on health, including the blurring of the traditional distinction between domestic and foreign spheres. Indeed, only a few urgent public health risks or emergencies remain solely within the purview of national or state authorities. ${ }^{10}$ In the past, the World Health Organization has played an important role in the coordination and implementation of international health law.

" Nick Drager \& Robert Beaglehole, "Globalization: changing the public health landscape" (2001) 79 Bulletin of the World Health Organization 803 at 803.

UN WHA. 54th Ass., 9th Plen. MIg., Global health securin: epidemic alert and response, WHIA 54. 14 (?חก)

"' As noted by Dr. Lee Jong-wrook, WHO Director-General, commenting on the revised IHR: "This is a major step lorward for international health... These new regulations recognize that diseases do not respect national boundaries," in WHO, Press Release. "World Health Assembly adopts new international Health Regulations: New rules govern national and international response to disease outbreaks" (23 May 2005), online: WHO <uww.who.int/mediacentre/news/releases/2005/pr_wha03/en/ index.html> 
The WHO, created in 1948, is the United Nations' specialized health agency " and has as its primary mission the "attainment by all peoples of the highest possible level of health."'2 Since its creation, the WHO's governance structure has been characterized by the pervasiveness of state-sovereignty and state interests, what scholars have called a "statecentric" or "Westphalian"13 approach in shaping the global public health order. This "Westphalian" approach, which adopts principles of sovereignty and non-intervention, is depicted within the WHO's original version of the International Health Regulations (IHR). However, globalization, along with other factors, has required the WHO to evolve from a top-down to a top-up, pro-active, or "post-Westphalian" approach to public health governance. This emerging global governance order is characterized by its multiple actors (which include not only states and intergovernmental organizations but also NGOs and even the media), by its organizational forms (networks versus territories) and as well by its changing arrangements (a preference for international collaboration over rigid state sovereignty).

Article 2 of the WHO's Constitution specifies that its functions include "to act as the directing and coordinating authority on international health work" and "to furnish appropriate technical assistance and, in emergencies, necessary aid upon the request or acceptance of Governments." 14 National sovereignty over domestic health policy will present an obstacle to the WHO's global governance mission unless the WHO adopts a more active and effective leadership role in international collaboration. The WHO's capacity to achieve its mandate is dependant on the political consensus of its member states and on the organization's existing and past successes in contributing to global health law. ${ }^{\text {Is }}$ With the revision of its IHR and its existing disease surveillance networks, the WHO is attempting to fulfill its mandate successfully.

Still, some scholars are skeptical about the emergence of a real new global governance order. They argue that:

As long as the interests of states and the interests of intergovernmental organizations are aligned, it is entirely possible that the WHO will continue to acquire new authority to combat public health scourges. The true test of the new public health order will come when international officials seek to assert authority in areas in which states - especially powerful countries ... lave divergent interesıs. ${ }^{16}$

Within the terms of art. 57 of the Charler of the Unifed Nasions.

UN WHO. Constitution of the W'orld Health Organization (22 July 1946) at art. I, online: WHO <hitp://w3. whosea,org/aboutsearo/pdf/const.pdfs.

Supra note 5 at 50; Lawrence O. Gostin, "International Infectious Disease Law: Revision of the World Health Organization's International Health Regulations" (2 June 2004) 291 JAMA 2623.

Supra note 12.

Allyn L. Taylor. "Global governance, international health law and WHO: looking lowards the future" (2002) 80 Bulletin of the World Health Organization 975 at 979.

Laurence R. Helfer, "Politics, Power, and Public Health: A Comment on Public IJealth's 'New World Order"' (Comment presented at the conference on SARS. Public Health and Global Governance. Temple University Beasley School of L.aw. March 2004). online: <hitp://aw.vanderbilt.edu/faculty/ pubs/helfer-politics.\%20power,\%20public\%20health.pup 


\section{THE ORIGINAL (1969) VERSION OF THE INTERNATIONAI. HEALTH REgULATIONS AND ITS LIMITATIONS}

According to art. 2 of the WHO's Constitution, in order for the WHO to achieve its mission, it is given the power to propose regulations and recommendations "with respect to international health matters."17 More specifically, the World Health Assembly, the WHO's supreme decision-making body, has been granted the power to adopt conventions or agreements (art. 19), adopt regulations (art. 21) and make recommendations "with respect to any matter within the competence of the Organization" (art. 23). It is within this capacity that the WHO has adopted the IHR, which have become binding for all member states.

The original incarnation of the International Health Regulations (IHR) were the International Sanitary Regulations, ${ }^{19}$ which were adopted in 1951 with the purpose of consolidating and harmonizing a piecemeal collection of international sanitary conventions. ${ }^{19}$ When, in the late sixties, the WHO opted to change the International Sanitary Regulations to the IHR, the traditional regime of disease control was left unchanged. Likewise, the modifications introduced in 1973 and 1981 constituted only negligible changes to the IHR. Consequently, the original version, with its subsequent modifications, represented a significant practical failure in the achievement of the IHR's core goal.

Of tremendous importance, the IHR have treaty status under international law. ${ }^{20}$ Originally a multilateral initiative among states, they remain the only legally binding instrument for the control of infectious diseases and provide a global surveillance tool for the international spread of communicable diseases. ${ }^{21}$ By ensuring "maximum security against the international spread of diseases with a minimum interference with world traffic," 22 the IHR address "public health emergencies of international concern."23

The narrow scope of the original IHR, which is based on the principle of sovereignty and non-intervention, as they are limited to the interaction between and among states, contributed to their irrelevant and obsolete character. For the IHR to constitute an effective governance instrument, fundamental changes had to be made. As specified by the WHO, some of the limitations of the original IHR included: their narrow coverage (limiting their scope to only cholera, plague and yellow fever), their dependence on official notifications made by member states, the absence of mechanisms for collaboration (between the WHO and countries), the lack of incentives to encourage member compliance, a lack of enforcement mechanisms and the lack of risk-specific measures in order to coordinate activities in the case of a disease

UN WHO, Global Crises-Global Solutions: Managing public heallh emergencies of international concern through the revised International Healh Regulations. WHO/CDS/CSR/GAR/20024 (Geneva:WHO, 2002) at 2.

1" Fidler, supra note 5 at 32

:" UN ILC, Vienna Convention on the Law of Treaties, as adopted on 22 May 1969 by the United Nations Conference on the l.aws of 'Treatics, Vienua, art. 2.I(a)

$\therefore \quad$ Supra note 18 at 3.

"2 UN WHA, International Healih Regulations (Geneva: WHO, 1969) at Foreword, online. WHO <ht1p:// policy.who.int/cgi-bin/om_isapi dil?infobase=lhreg\&soltpage=Browse_Frame_Pg $42>$

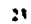


outbreak. ${ }^{24}$ Furthermore, the original version of the IHR did not achieve the necessary balance between the protection of public health and its interference with international commerce. For a decade, the WHO has recognized the shortcomings of the IHR and has proceeded to their revision." Indeed, only a "broader, flexible approach that legitimizes dynamic public health action"26 could contribute to the achievement of the WHO's global health governance mission.

\section{THE Revised International Health Regulations (2005)}

On 23 May 2005, the World Health Assembly adopted the revised International Health Regulations, to be referred to as the "International Health Regulations (2005)," characterized as the "key global instrument for protection against the international spread of disease." ${ }^{28}$ This new version of the IHR aims to overcome the shortcomings presented in the original IHR by expanding their mission and scope to "prevent, protect against, control and provide a public health response to the international spread of disease in ways that are commensurate with and restricted to public health risks, and which avoid unnecessary interference with international traffic and trade." ${ }^{.29}$ The revised instrument further requires that the implementation of the IHR shall be conducted with full respect for the fundamental human rights and dignity of persons. ${ }^{30}$

The original (1969) IHR adopted a disease-specific approach, obliging states to notify the WHO of the occurrence (and end) of cholera, plague and yellow fever outbreaks in their territories. ${ }^{31}$ It listed the maximum measures applicable during such outbreaks, including hygiene measures at ports and airports (e.g. the de-ratting, disinfecting and de-insecting of ships and aircrafts) and health-related rules for international trade and travel (e.g. health and vaccination certificates for travelers).

The revised IHR (2005), however, have now achieved a more flexible and broader approach to public health action, as demonstrated by its complex system for the determination and notification of events that constitute a "public health emergency of international concem."

In the control and surveillance of infectious diseases, not all disease occurrences within member states will require notification to the WHO. The revised IHR elaborate a specific decision instrument that member states must adhere to in order to identify diseases that have international concern. Firstly, the revised IHR define a "public health emergency of international concern" as an extraordinary event which is determined "to constitute a public health risk to other States through the international spread of disease" and "to potentially

\section{Supra note 18 at 3.}

UN WHA, 48th Ass., 12th Plen. Mtg., Revision and updaling of the International Health Regulations. WHA48.7 (1995).

Gostin, supra nole 13 at 2625.

Revised IHR, supra note 23 at foreword.

Ibid.

lbid., ant. 2.

ibid., ant 3.

Supra note 22, ant. I, defining "diseases subject to the Regulations." 
require a coordinated international response." Furthermore, an "event" is defined as "a manifestation of disease or an occurrence that creates a potential for disease." ${ }^{\prime 2}$

Because the revised IHR combine the old "disease-specific approach," included in the original (1969) IHR, with a new algorithm or decision instrument, ${ }^{33}$ this new approach allows for more flexibility. As required under the original IHR, member states are again required under the revised IHR to notify the WHO of any isolated case of smallpox, poliomyelitis (due to wild type poliovirus), human influenza (caused by a new subtype) and severe acute respiratory syndrome (SARS). These designated diseases are classified as "unexpected" or "unusual" in nature.

The revised IHR also classify a list of diseases that have the "ability to cause serious public health impact and to spread rapidly internationally." These diseases include: cholera, pneumonic plague, yellow fever, viral haemorrhagic fevers (Ebola, Lassa, Marburg), West Nile fever, or other diseases that are of special national or regional concern (dengue fever, Rift Valley fever, and meningococcal disease). ${ }^{34}$ In the presence of all these cases, member states are required to use the decision instrument in order to determine if notification is required.

Moreover, in all other cases, where the disease occurrence has a potential international public health concern but is not specifically mentioned in the revised IHR, the proposed algorithm or decision instrument is used to determine the need for notification.

The current version of the algorithm contains the following criteria: (a) seriousness, (b) unexpectedness or unusualness, (c) significant risk of international spread and (d) significant risk of international travel or trade restrictions." If the event meets any two of the four criteria (a-d) listed, the state member shall notify the WHO of the event pursuant to art. 6 of the revised IHR. It should also be noted that all the given examples found in the algorithm are not binding but only indicative in order to aid the states in interpreting the decision instrument. ${ }^{36}$

It is expected that by adopting this new framework all public health threats that could have international consequences could be properly identified (and noted), including novel threats (for example, natural or intentional release of pathogens, chemicals or radio-nuclear materials). Yet, for the framework to be effective, the WHO and member states should provide guidance and technical assistance for maintaining proper national surveillance standards. ${ }^{37}$

Indeed, effective surveillance results in good global health governance because it will provide "adequate and timely data to allow public health responses to be planned and

12 Supra note 23, art. 1.

"II Ibid., Annex 2.

"Ibid.

is Ibid.

u Ibid.

1 Gostin, supra note 13 at 2625 
implemented. ${ }^{38}$ Under the new IHR, surveillance is defined as "the systematic ongoing collection, collation and analysis of data for public health purposes and the timely dissemination of public health information for assessment and public health response as necessary. ${ }^{39}$ Moreover, the new IHR serve as the legal framework for the WHO's alert and response activities. ${ }^{40}$ The obligations contained in the IHR for member states to notify the WHO of the occurrence of public health emergencies of international concern, and the information gathered by non-governmental sources, are the comerstone of the WHO's global surveillance activities.

Under this legal framework, the WHO has developed and coordinated mechanisms for epidemic alert and responses, such as the Communicable Disease Surveillance and Response (CSR), the Global Outbreak Alert and Response Network (GOARN) and the Global Public Health Intelligence Network (GPHIN).

The CSR endeavours "to reach global health security" by (i) the containment of known risks such as leading epidemic and emerging diseases with specific global surveillance and response networks; (ii) the rapid and effective response to unexpected outbreaks using epidemic intelligence systems that gather and verify outbreak information and coordinate responses to outbreaks of international importance; and (iii) by improving preparedness by building or strengthening national capacities, especially in developing countries. The foundation of the CSR vision is global partnership.

In April 2000, the WHO launched the GOARN as a "mechanism for keeping the volatile microbial world under close surveillance and ensuring that outbreaks are quickly detected and contained."41 The GOARN is an operational system which interlinks 120 existing networks for the detection, verification and containment of epidemics in real time. It contributes to global health security by ensuring that appropriate technical assistance reaches affected member states rapidly and contributing to long-term epidemic preparedness and capacity building, thereby combating the international spread of outbreaks of infectious/communicable diseases. ${ }^{42}$

Through the GOARN the WHO also aims to enhance the coordinated delivery of international assistance in support of local efforts by partners, strengthen local infrastructure to reduce morbidity and mortality and prevent the spread of disease." The GOARN also interlinks technical and operational resources from scientific institutions, medical and

Supra note 23, art. 1.

UN WHA, 54th Ass., provisional agenda item 13.3, Global health security --epidemic alert and response, Repon by the Secretariat. A54/9 (2001), onlint: WHO < www: who.intgb/ebwha/pof_files/ WHA54/ca549.pdBs.

UN WHO. Department of Communicable Disease, Globul defence against the infectious disease threat, WHO/CDS/2003.15 (Geneva: WHO, 2003) at 58, online: WHO <www. who.int/infectious-discascnews/cds2002/index.htm|>.

$\because \quad$ UN WHO, Communicable Disease Surveillance \& Response, Global Outbreak Alen \& Response Network, online: WHO <www. Who. inU/csr/outbreaknetwork/en/>

"UN WHO. Department of Communicable Disease Surveillance and Response, Clobal Outbreak Aler and Response: Report of a WHO meering. WHO/CDS/CSR/2000.3 (Geneva: WHO, 2000), online WHO <www. who in $/$ csr/resources/publications/surveillance/whocdsesr2003.pdP 
surveillance initiatives, regional technical networks, United Nations organizations (such as UNICEF) and international humanitarian organizations (such as the Red Cross and Doctors Without Borders).

In addition to the GOARN, the WHO also relies on the GPHIN, an Internet-based surveillance system developed and maintained by Health Canada. The GPHIN consists of an Internet-based, time sensitive warning system for global public health events (from outbreaks ranging from environmental disasters to bioterrorism). The system continuously and systematically scans the World Wide Web looking for reports of suspicious disease events (for example, communicable diseases and syndromes). ${ }^{\text {th }}$

The effectiveness of both the GOARN and the GPHIN was proven during the 2003 SARS outbreak, as they were instrumental in the early reporting of SARS outbreaks and provided ongoing support and critical operational capacity to health authorities worldwide. The WHO's coordination of these networks was essential in the development of the necessary tools for the containment of the outbreak, as noted by the World Health Assembly in resolution WHA56.29.4"

\section{A. REvised INTERNATIONAL HEAlth Regulations: CoRf Obi.jgations}

The revised IHR also create core obligations for member states and improve core obligations for the WHO within a more flexible framework than the original IHR. For example, member states would have the option of making confidential provisional notifications to the WHO, instead of the old rule of mandatory publication in the Weekly Epidemiological Record. Yet, member states would have to respond to requests for verification of information or consultations regarding urgent national public health risks and would have to apply measures recommended by the WHO during a public health emergency. In addition, under the revised IHR, the WHO's Director-General would have the authority to determine whether an event constitutes a public health emergency of international concern. This would be done according to the procedure set up in the decision instrument and on information received in particular from the affected state as well as other member states and non-governmental sources. As specified in the IHR, if the Director-General considers that a public health emergency of international concern is occurring, the Director-General should consult with the affected country regarding this preliminary determination. ${ }^{46}$ If there is agreement between both parties regarding the determination, then they should seek the advice of the new Emergency Committee concerning the appropriate temporary recommendations to be followed. However, if no consensus is reached, the Director-General shall make the final determination, after considering the views of the Emergency Committee. ${ }^{47}$

Seeking to improve the WHO's surveillance capacities, the revised IHR extends the WHO's legal authority to disclose disease outbreaks according to information obtained from reliable non-governmental sources and real-time event management. Article 10(4) of the

UN WHO, "Global infectious disease surveillance," Fact sheet No. 200 (June 1998), online: W11O <www, who int/mediacentre/ficts/uets//s200/en/>.

Supra note 7.

lbid. ant 12.

Ibid. ant $49(5)$. 
revised IHR further specifies that when the WHO receives information and offers to collaborate with the states, if the states refuse to collaborate, the WHO may share the information with other member states (provided that the disclosure is justified due to the magnitude of the public health risk).

Further core obligations for the WHO include the duty "to respond to the needs of member states regarding the interpretation and implementation of the regulations" and to "provide recommended measures for use by member states during public health emergencies of international concern, based on a consistent process of risk verification and assessment. ${ }^{.48}$

In turn, under the revised IHR, international conveyance operators must provide on-board inspections and control measures to ensure that diseases are not transmitted. Additionally, international conveyance operators are required to facilitate the inspections of conveyance, containers and cargo, the medical examinations of persons aboard the conveyance and the application of other health measures under the proposed regulations. Furthermore, conveyance operators are required to maintain their conveyance in a manner that does not contribute to the international spread of diseases. ${ }^{49}$

\section{B. Revised International Heal.tu Regulations: Core Capacities}

The original IHR contain limited core capacities ("elemental level of activity needed to fulfill the core obligations") ${ }^{\text {so }}$ such as hygiene measures on international carriers and at borders. The revised IHR seek to improve the requirements for national public health systems and for core capacity requirements for surveillance and response at two levels: local community and intermediate public response levels. ${ }^{31}$

Currently, member states should use existing national structures and resources to meet their core capacity requirement under the regulations, with regard to surveillance, reporting, notification, verification, response and collaboration activities, including activities

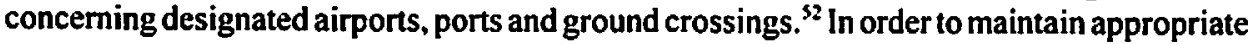
standards, the revised IHR require member states to assess, within two years of the entry into force of the regulations, their ability to meet the minimum requirements stipulated in the IHR and should implement plans of actions to ensure their attainment. ${ }^{53}$ However, to guarantec the practical success of these new provisions and to make states truly accountable for their performance, the WHO would be required to set performance standards and measure outcomes. In addition, in order for these new provisions to be practically meaningful, the strengthening of national public health systems, especially in developing countries, is required.

Moreover, the new IHR include several new core capacities for the WHO. Among these are the provision of a 24-hour service to coordinate international responses to urgent public 
health emergencies threatening member states, the development of a consistent and transparent process for the assessment of urgent intemational risks and a newly created Emergency Committee. Furthermore, the WHO would have the authority to issue recommendations regarding the application of selected health measures. The WHO would then be empowered to issue temporary recommendations (such as containment and control measures) to the affected country, to other member states, or to both, in the face of an imminent threat or risk of international spread of disease or a disruption of international travel and trade. .4

\section{REVISED INTERNATIONAL HEALTH REgULATIONS: RESPECT FOR HUMAN RigHTS}

The WHO's Constitution defines "health" as "a state of complete physical, mental and social well-being and not merely the absence of disease or infirmity." Moreover, the Preamble states that the "enjoyment of the highest attainable standard of health is one of the fundamental rights of every human being without distinction of race, religion, political belief, economic or social condition."ss

The right to health was further recognized as a fundamental human right in the Universal Declaration of Human Rights. ${ }^{36}$ By doing so, the UDHR laid down the foundations of the international legal framework for the right to health. This right has since been codified in numerous legally binding international and regional human rights treaties. ${ }^{57}$

However, the exercise of fundamental rights is not absolute within the scope of public health. The WHO and the international community have widely recognized that fundamental rights can be limited for public health reasons, for instance, in the control of infectious diseases. However, the curtailment of this fundamental right must be done in accordance with international human rights standards and the law. Namely, it must be done only when strictly necessary for the promotion and protection of the general welfare of the population, in a proportional manner, subject to review and of limited duration.

A human rights approach to public health is imperative, as it recognizes "health" as both a fundamental right and a "global public good," and aims to promote and strengthen the wellbeing of all peoples and societies. It is in this context that the WHO, in the revised IHR,

sbid., ant. 15.

Supra note 12.

UN, Universal Declaration of Human Rights, GA Res. 217A(III), UN GAOR. 3d Sess., UN Doc. A/810 (1948), ant. 25 [UDHR].

Some examples of international Ireaties from the UN Office of the High Commissioner for Human Rights include: International Covenant on Economic. Social and Cultural Rights. GA Res. 2200A (XXI), UN HCHR (adopted 1966, in force 1976), art. 12; Convemtion on the Elimination of All Forms of Discrimination Against Women, GA Res. 34/180. UN HCHR (adopted 1979, in force 1981). art. 12: International Convention on the Elimination of All Forms of Racial Discrimination. GA Res. 2106 (XX), UN HClIR (adopled 1965, in foree 1969), art. 5: and ('onvention the Rights of the ("Wild. GA Res. 44/25 (adopted 1989, in force 1990), art. 24. Some regional instruments include: OAS. Genreal Assembly, 18th Sess., Additional Protocol to the American ('onvention on Human Rights in the .trea of Economic, Social and Cullural Rights: "Protocol of San Salvador." Treaty Series. No. 69 (1988) and African [Banjul] Charter on Human and People's Rights. OAU Doc. CAB/L.EG/67/3 rev. 5.21 I.L.M. 58 (1982), art. 16. 
"recognize[s] health as a global public good"ss and has incorporated the protection of human rights through non-discrimination measures and the recognition of rights under international law.

As has been suggested by several experts, the Siracusa Principles ${ }^{59}$ should be implemented to balance the needs of public health and human rights. According to the Siracusa Principles, public health can provide legitimate grounds in order for states to limit certain rights when addressing serious health threats to individual members of its population. These measures must be "specifically aimed at preventing disease or injury or providing care for the sick and injured." measures shall be proportional to the exigencies of the threat and must respect the WHO's international health regulations.

\section{THE NEW INTERNATIONAL HEALTH REGULATIONS (2005): A Step Forward in Modern Global Public Health Governance?}

The revised IHR (2005) have the potential to provide substantial improvements in the coordination of international response to the spread of diseases. Contrary to the original (1969) IHR, the revised IHR clearly establish the relationship between the WHO and its member states by specifying the respective roles and responsibilities of each party. The revised IHR require that National IHR Focal Points are designated and established in each member state to promote better communication between the member states and the WHO. ${ }^{.1}$ As well, not limiting the HHR to a disease-specific approach but rather adopting the decision instrument will be fundamental in the assessment and identification of public health threats to prevent outbreaks that may result in pandemics.

Striving to claim a more prevalent role in global health governance, the WHO plays a more authoritative and important function within the revised IHR in the global detection, prevention and control of diseases than in the original IHR. Accordingly, the WHO may consider reports received from sources other than notifications and consultations from member states ${ }^{62}$ and may make verifications to deterinine if the threat is a "public health emergency of international concern." ${ }^{63}$ It is the Director-General who has the mandate to determine what constitutes a "public health emergency of international concern"64 and, pursuant to the criteria established in art. 17 of the IHR (2005), the WHO has the power to make recommended procedures to address disease threats. ${ }^{65}$ The points of entry into states. travel, health documents, the flow of trade and conveyances are also all controlled and treated with relevant health measures within the revised IHR.

S*. Supra note 18 at 10.

5. Siracusa Principles on the Limitation and Derogation Provisions in the linernationat Covenant on Civil and Political Rights. UN ESC. Sub-Commission on Prevention of Discrimination and Protection of Minorities. Annex, UN Doc. E/CN.4/1985/4 [Siracusa Principles].

lbid, ant 25.

Supra note 23 , an. 4

Ibid., an. 9.

lbid., art. 10.

lbid, art. 12.

lbid. arts. 15, 16. 
Theoretically, the revised IHR provide an important framework for the WHO's control in public health policy but it is questionable how effective a tool the IHR will be in practice. The new IHR fail to resolve the problem of resource allocation and, in particular, how developing countries will comply with the new requirements and contribute to the modernization and strengthening of the WHO's surveillance system. The revised IHR also remain silent regarding important ethical challenges such as the duty of care in the context of unknown risks, the balance between individual privacy rights and the public's right to know $^{66}$ and the use of restrictive measures. By limiting to offer only general definitions of measures such as isolation, quarantine or other compulsory measures, the new IHR also fail to provide legal standards and fair processes. ${ }^{67}$ Moreover, another lacuna in the revised IHR concerns the absence of explicit sanctions when there is non-compliance by member states.

One of the ways to promote state compliance is through a system that promotes flexibility and creates incentives for member states. It should be noted that one of the main shortcomings of the original IHR was state compliance. Adhering to the IHR and reporting a disease outbreak to the WHO meant possible harmful results for national economies due to impediments on national trade, tourism and commerce. It is due to protection of national interests and state sovereignty that states fail to comply with global health norms. Therefore, the WHO must establish incentives in order to increase state conformity with the IHR.

Although the IHR have treaty status and are a legally binding instrument, member states are not precluded from implementing additional health measures pursuant to national and international laws, ${ }^{68}$ nor are they prohibited from adopting reservations to the IHR. ${ }^{69}$ The only limitation posed on these state capacities is that all additional measures or reservations must be consistent with the purpose and objective of the IHR. Concerning additional health measures, the WHO has the authority to assess the measures taken and can even request the state to reconsider its activities. ${ }^{30}$ However, the WHO's control concerning the reservation process is less apparent. The Director-General is notified of the reservations but whether or not this reservation is to be accepted is dependent on the consent of other member states and not the WHO." The authority of the World Health Assembly is implicated only after the reserving state has refused to withdraw its reservation following an objection by one-third of the member states. ${ }^{72}$ The WHO's current governance structure demonstrates that the principle of state sovereignty has not been fully abandoned within the IHR, which will possibly provide for greater state compliance.

By revising and updating the International Health Regulations, the WHO has attempted to enhance capacity building in global public health. It is expected that, by adopting a broad and flexible approach to global health security, the new IHR will have greater effectiveness and relevance against the threat of international spread of infectious diseases. This revision

C. Shawn Tracy. Ross E.G. Upshur \& Abdallah S. Daar. "Avian Influenza and Pandemics." L.tter ko the Editor (5 May 2005) $352 \mathrm{New}$ lingland Journal of Medicine 1928

Gostin. stupra note 13 at 2626 .

Supra note 23, art. 43.

Ibid., ant. 62(1).

Ibid., art. 62(4).

Ibid., art. 62(5).

Ibid., an. 62(9). 
process has demonstrated the WHO's attempt to reclaim its leadership role in securing global health governance.

\section{Conclusion}

The WHO's primary function is the protection and promotion of global health. However, global health governance has been characterized for many decades as weak, "burdened by antiquated international law assumptions." neither ideal nor realistic due to obstacles such as state sovereignty and the complexity of emerging global health issues. However, international collaboration, which requires states to relinquish some aspect of their sovereignty for global public good, is necessary when faced with the effects of globalization and the imminent threat of the spread of infectious diseases across international borders.

The original IHR (1969) provided a framework for global health security, yet persistent non-compliance and adherence to outdated notions of rigid state sovereignty and public health have made them virtually obsolete and irrelevant. The new IHR (2005) have the potential to serve as a model for effective public health governance and to ensure the maintenance of an adequate surveillance system. They have been updated in order to meet the demands of contemporary global surveillance and control of international outbreaks of infectious diseases. With the revised IHR and existing surveillance systems, it still remains to be seen whether the WHO can fulfill its mandate and act as a leading coordinator in public health policy. 